\title{
Tolerance between religions through the role of local wisdom and religious moderation
}

\begin{tabular}{|c|c|}
\hline \multicolumn{2}{|c|}{$\begin{array}{l}\text { Authors: } \\
\text { Hadi Pajarianto }^{1} \text { (1) } \\
\text { Imam Pribadi }{ }^{1} \text { (D) } \\
\text { Puspa Sari }{ }^{2}\end{array}$} \\
\hline \multicolumn{2}{|c|}{$\begin{array}{l}\text { Affiliations: } \\
{ }^{1} \text { Early Childhood Education } \\
\text { Programs, Faculty of Teacher } \\
\text { Training and Education, } \\
\text { Muhammadiyah University of } \\
\text { Palopo, Palopo, Indonesia }\end{array}$} \\
\hline \multicolumn{2}{|c|}{$\begin{array}{l}{ }^{2} \text { English Language Education, } \\
\text { Faculty of Teacher Training } \\
\text { and Education, } \\
\text { Muhammadiyah University of } \\
\text { Palopo, Palopo, Indonesia }\end{array}$} \\
\hline \multicolumn{2}{|c|}{$\begin{array}{l}\text { Corresponding author: } \\
\text { Hadi Pajarianto, } \\
\text { hadipajarianto@umpalopo. } \\
\text { ac.id }\end{array}$} \\
\hline \multicolumn{2}{|c|}{$\begin{array}{l}\text { Dates: } \\
\text { Received: } 04 \text { Aug. } 2021 \\
\text { Accepted: } 22 \text { Nov. } 2021 \\
\text { Published: } 27 \text { Jan. } 2022\end{array}$} \\
\hline \multicolumn{2}{|c|}{$\begin{array}{l}\text { How to cite this article } \\
\text { Pajarianto, H., Pribadi, I. \& } \\
\text { Sari, P., 2022, 'Tolerance } \\
\text { between religions through } \\
\text { the role of local wisdom and } \\
\text { religious moderation', HTS } \\
\text { Teologiese Studies/ } \\
\text { Theological Studies 78(4), } \\
\text { a7043. https://doi. } \\
\text { org/10.4102/hts.v78i4.7043 }\end{array}$} \\
\hline \multicolumn{2}{|c|}{$\begin{array}{l}\text { Copyright: } \\
\text { (c) 2022. The Authors } \\
\text { Licensee: AOSIS. This } \\
\text { is licensed under the } \\
\text { Creative Commons } \\
\text { Attribution License. }\end{array}$} \\
\hline \multicolumn{2}{|l|}{ Read online: } \\
\hline 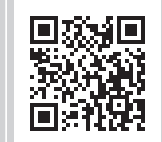 & $\begin{array}{l}\text { Scan this } Q R \\
\text { code with your } \\
\text { smart phone or } \\
\text { mobile device } \\
\text { to read online. }\end{array}$ \\
\hline
\end{tabular}

Religion and culture play a central role in building harmonious relations between followers of different religions, both within the nuclear family and in the extended family. This study examines the revitalisation of religious moderation with a cultural approach in strengthening tolerance. Data was obtained qualitatively from in-depth interviews and observations of families of different religions, religious leaders, traditional leaders, and other relevant informants. The research findings show that the family institution is the most crucial place in carrying out moderate religious culturalisation through the local wisdom values of kasiuluran [kinship], tengko situru [togetherness], and karapasan [tenacity]. Institutionally, traditional leaders, religious leaders, and clans in Tongkonan encourage peace in society, both in traditional and religious activities. Meanwhile, religious celebrations, traditional ceremonies, and community activities are occasions to socialise and interact by placing a firm tolerance for religious differences.

Contribution: This study contributes to the realisation of tolerance through the application of moderate religious values and local wisdom that the world needs today. Strengthening interreligious relations is very important because the position of religion is complex and sensitive. This contribution is crucial in the midst of the rampant issue of radicalism in Indonesia lately.

Keywords: tolerance; local wisdom; religious moderation; culture; harmony.

\section{Introduction}

Nowadays, humans are faced with conflict situations and even wars that ravage the economy, and destroy the future of children. It happens if the triggers such as political, cultural, ethnic, racial, and religious divisions are strengthened (Syarif 2019; Yazdani 2020). Empirically, this gap can be seen from the increasing violence against Ahmadiyya and Shia Muslims, the closure of Christian churches, and the tension between radical groups and the dominant Muslim community (Rogers 2018). Other countries such as Sri Lanka and Myanmar have also experienced problems in religious relations, especially between Muslims and Buddhists (Frydenlund 2015). The same interreligious case surfaced between Muslim and Hindu fundamentalists in India, caused by expressions that insult other religions (Singh 2018). This is unfortunate given that all religions teach love and peace to all humans. Islam further teaches us to pursue peace by making the most of similarities and minimising inequality (Wani, Abdullah \& Chang 2015). Religious leaders and religious people are highly respected mediators in their communities and are in a prominent position to promote peace (Glazier 2018).

Interaction between cultures should be stimulated because it can encourage a better understanding of the differences (Verkuyten, Yogeeswaran \& Adelman 2019). This study explores how people of different religions in Indonesia use cultural zones to build understanding with one another. It focuses on the study of Alor as an identity that has survived since ancient times which is used to build tolerance (Tambunan 2018). This research however, does not include the involvement of traditional leaders and religious leaders in strengthening inter-religious harmony. In a study conducted in Australia, the possibility for young people to experience discrimination was found to be significant, it however, also recognised the benefits and opportunities of cultural and social diversity (Markus 2017). Thus, the concept of inter-religious harmony must be taken seriously by continuously exploring it in any part of the world so that the tolerance between religious communities can be improved and enhanced for the better.

This study explores three essential aspects of religious moderation through a cultural approach of: application of wisdom values, institutional roles consisting of traditional and religious leaders, and the socialisation processes that emphasise strengthening of tolerance. This study 
serves to strengthen the tolerance between different religious communities with the support of local wisdom and religious values in a country with a plural society. Discrimination and even anarchy carried out by a community group against another community are contrary to human values and a religious and cultural plurality (Miftah 2016). In this situation, a moderate religious attitude is needed, standing above humanity regardless of ethnicity, race, and religion (Hasan 2018).

Values that are very important to foster tolerance come from religion or ancestral beliefs, as beliefs and memories of the past are used as guidelines for carrying out any religious rituals and even as a source of moral values (Idaman 2012). On the contrary, archipelago society can maintain its deep authenticity even after being affected by these interactions (Rahardjo 2002). Three essential things in the advice of wise men and late kings that are still relevant today are as follows: (1) equality of degrees as God's creation; (2) human desires that consistently tend to do good; and (3) humans in building values and socio-cultural institutions always try to achieve harmony between collective interests and individual interests (Mattulada 2015). The social identity attached to a community group distinguishes it from other groups. This is reflected in their language, traditions, clothing, and the norms and values they believe in (Haryanto 2015).

In South Sulawesi Province, Indonesia, the people are from four most prominent ethnic groups - the Bugis, Makassar, Toraja, and Mandar tribes (Mattulada 1982). The Toraja tribe is unique in upholding tolerance between different religious communities, despite the fact that sometimes one household can consist of members from different religions. The name Toraja was initially given to the Bugis-Sidendreng tribe and the Luwu people. The word Toraja comes from joining two words: 'To' and 'Riaja'. The word 'To' means people or humans (bugis) and 'Riaja' means above. So, Toraja means people who live at the top or in the highlands (mountains) as opposed to the word 'Luu' which means coastal people, who previously had a predominance in the highlands (Waterson 2009). Toraja has succeeded in selective absorption and resistance to cultural forces from the lowlands dominated by Islamic forces (Bigalke 2005).

The contribution of this study will affirm the importance of family, cultural values, involvement of religious figures, and the importance of socialisation forums in encouraging the creation of harmony in the context of positive tolerance. Cultural and religious values such as hospitality are the key to success, lineage is a gift, and serving guests also bring happiness as an ethos that emphasises hard work and good behaviour. Therefore, family and cultural values have become an influential instrument in religious moderation (Prasojo et al. 2019). Religious moderation enculturated in various segments of people's lives will improve the quality of tolerance.

\section{Literature review Genealogy roots of Islamic moderation}

Indonesia has hundreds of local religions and major world religions, tribes, and customs (Astuti et al. 2019; Sumadi et al. 2019), which are bound by the basic principle of Bhineka Tunggal Ika, unity in diversity - the official national motto of Indonesia (Nakaya 2018). The plurality of the Indonesian society requires a unifying instrument. From the beginning, all community members have been proactively passionate about preserving the local colours as the nation's strength (Arifinsyah, Andy \& Damanik 2020). Moderate Islam became one of the unifying instruments inspired by the term wasathiyah. Wasathiyah originated from the word wasath, which can be translated as sawa'un [the middle of two boundaries with justice] (Dodego \& Witro 2020). The word wasathiyah comprises the three main characteristics of Islam, namely, tawasuth [middle], ta'adul [fair] and tawazun [balanced] (Muhajir 2018). Therefore, religious moderation means placing oneself in the middle between the extreme right and left attitudes, in seeing and solving problems (Dodego \& Witro 2020). These negative attitudes can take various forms, ranging from harsh and excessive speech, a closed attitude towards other groups, to extreme actions such as destroying other people's lives with violence, and inclusively respecting the religious practices of others with different beliefs (Hernawan et al. 2021; Shihab 2019).

Religious moderation is part of Islamic teachings, as it is found in the Qu'ran. Hence, religious moderation is an attitude that stands in the middle, not taking sides neither left nor right, but being in the centre of seeing and solving a problem. The purpose of religious moderation is to create a tolerant, peaceful, and harmonious atmosphere in religion and nation, and to support a multicultural life (Dodego \& Witro 2020). Theologically, the attitude of tawasuth or moderation is reflected in God's commands in Islam, which are contained in QS. Al-Baqarah verse 143 states: And thus we have made you a just community that you will be witnesses over the people, and the Messenger will be a witness over you (Departemen Agama 2005).

The concept of wasathiyah can be the basis of thinking for the Muslim communities in the modern era to build relationships with other civilisations, especially Western civilisation. Strengthening discourse and action related to religious moderation is both a challenge and opportunity to encourage a more moderate interpretation of religious texts (Junaedi 2019), and reduce the potential for religious radicalism that can trigger conflict (Ibrahim, Prasojo \& Sulaiman 2019). It is crucial to transfigure the antisocial group's destructive actions into creative and cooperative energy in order to improve people's productivity (Latif 2011). Moderate and tolerant religious principles are needed to strengthen tolerance as an inner, deep dimension of religion. Humans can live side by side in harmony because of the call of faith (Mu'ti \& Islam 2009). 
Many local values can be used as a spirit to foster interreligious harmony. For example, the teachings about siangga, sikamali na Siangkarran [mutual respect, longing for each other, and helping each other] without discriminating against religious differences (Umar 2019). Almost all regions in Indonesia own this social asset, encouraging moderate, fair and balanced religious practices.

\section{Cultural approach}

Indonesia has a very high cultural and religious diversity. Until now, the Indonesian people still preserve their local wisdom to maintain the unity and integrity of the nation. Local wisdom is a significant social asset to build a moderate perspective, attitude, and religious behaviour (Kementrian Agama RI 2019). Among society's social assets is the culture of gotong royong - gotong means to lift or carry, and royong means together. In addition, another social asset is a culture of deliberation in solving all forms of problems (Kementrian Agama RI 2019).

The cultural approach aims to promote the human characteristics of humanity or develop the attitudes and behaviour of humans themselves (Hidayat 2015). Every ethnic, religious, racial, or ethnic community always express their culture as a value system in life. They can survive through unique ways of interacting with their environment. In simple terms, local wisdom is the ability to adapt, manage, and process the universe's resources for the common good (Pesurnay 2018). Local wisdom is sometimes also associated with myths, legends, and traditions. However, it also grows dynamically following human innovation and creativity (Effendi 2019). Religion teaches about theology and also the values in it according to the essence of humanity. Religion is the last resort in solving problems that humankind faces, including social, cultural, political, and religious problems (Husna \& Thohir 2020).

In the context of Islam, the da'wah approach can be the guiding force in building a harmonious relationship with the other religious groups' cultural mosaics. The spirit of Islam is a substantive spirit that is more concerned about the content than the container, as Islam can be expressed through various vehicles and symbols (Suparto 2009). The cultural approach can also be interpreted as an activity of interacting with different religions by paying attention to the potential and tendencies of humans as cultural beings in the broadest sense in order to produce a new culture with Islamic nuances or $d a^{\prime}$ wah activities by utilising local customs, traditions, arts, and culture in the process of leading an Islamic life. This concept is framed by Islamic teachings' views and value systems that carry the message of rahmatan lil alamin [a mercy to all creation].

The Toraja people have a unique culture that is used to foster tolerance between religious communities. It is called Rambu Solo, which is a death ceremony, and Rambu Tuka, a harvest ceremony (Pulubuhu et al. 2019). In this case, the Aluk Todolo belief manifested through the Rambu Solo and Rambu Tuka rituals for the Toraja people has become an integrator of social life and serves to maintain the Toraja peoples' identity (Handayani, Ahimsa-Putra \& Budiman 2020). Cultural values in society are also accompanied by cultural norms that are believed and implemented in a community. These cultural values and norms are the basic rules in conducting social interactions to regulate and control socio-cultural activities.

\section{Research methods}

Tana Toraja was chosen as the research location based on several reasons. Firstly, the robust Aluk Todolo culture (literally, past habits) is still dominated sociologically in Tana Toraja. This cultural root is still a prominent reference for the religious norms and values adopted by the Toraja people. Secondly, academically-pedagogically, the cultural approach is highly emphasised in solving nuclear and extended families' problems. Finally, politically, the terminology of majority and minority is no longer an intrinsic issue in Toraja because of the fact that people are affiliated based on family closeness, not on the basis of religion and ethnicity (Pajarianto \& Mahmud 2019).

This research was conducted using qualitative analysis. Qualitative methods are used to answer questions about experience, meaning, and perspective, most often from the participant's point of view (Hammarberg, Kirkman \& De Lacey 2016). Determination of data sources is carried out by purposive sampling, based on the specific characteristics that are closely related to previously known characteristics, in accordance with the research objectives. The subjects of this study were Muslim families who have family members of different religions in Tana Toraja, with as many as 21 participants. Data were collected using focus group discussions (FGDs) and in-depth interviews during the period from June 2020 to September 2020 in Tana Toraja for 4 months.

The steps or strategies to increase the credibility of the data and avoid data bias include: triangulating sources, namely matching data with different sources, and triangulating techniques, namely matching interview data with observations and FGDs (Bungin 2009). The data are analysed thematically and carried out through three stages: data reduction, data display, and conclusion and verification (Sugiyono 2017). In this way, the reliability of the data can be ensured and data bias can be minimised.

\section{Findings and discussion Value of local wisdom to strengthen tolerance}

The Toraja society is a society that lives communally, but individualism still exists. Even this attitude of individualism must remain subject to kada rapa', which means following what has been decided together (Muhiddin et al. 2020). Toraja people are familiar with the term Saroang in the form of community groups based on the status of their descendants. The Saroang group is highly considered in determining the 
decisions of families and even individuals who are members of the group, especially regarding decisions on customary implementation. The better the existence of a Saroang, the more prominent and more important his role in society will be. Thus, the self-representation of the Toraja people, especially self in the collective sense (we/us), can be seen from the existence of this Saroang (Muhiddin et al. 2020). Outside the Toraja area, many family associations were formed by Toraja people who migrated to strengthen kinship relations outside Toraja.

Researchers identified the values of local wisdom used by the people of Tana Toraja in maintaining a culture of tolerance that has been implemented as part of practising religion and culture. These values comprise: kasiuluran [kinship], tengko situru [togetherness], and karapasan [tenacity], which became the essence of Toraja kinship (see Table 1).

The research findings shown in Table 1 can be explained in detail as follows. Firstly, the value of kasiuluran [kinship] is applied by interacting and associating with other community members despite different religions, by emphasising communal lifestyles and interests of extended families, and prioritising family harmony despite different religions. Secondly, the value of tengko situru [togetherness] is practised by making religion a personal matter for each, providing support for other religious events both morally and materially, and providing full support to extended families who are holding traditional events. Lastly, karapasan [persistence] is implemented by maintaining peace in the community, feeling shame when violating tradition and religion, and obeying religious and traditional rules.

In Tana Toraja, it is common to have members from different religions in one household. Despite this, the family members respect each other individually and their religion. There is a philosophy of tangla napoka'tu rara, tangla napopoka book [blood relations in the family will not break, like a bone that does not crack]. Blood ties and kinship in the Tongkonan spirit become a strong glue even though there is a fragmentation of affiliation to specific religions and beliefs. Toraja people's faith can experience conversion at any time along with its openness to culture from outside, but brotherhood through blood ties is carried to death (interview, $\mathrm{Kr}, 2019)$.

For Toraja people, Tongkonan is the mother culture and the centre of social life because traditional values and norms

\begin{tabular}{lll}
\multicolumn{2}{l}{ TABLE 1: Focus, value, and findings on the value of local wisdom. } \\
\hline Focus & Value & Findings \\
\hline $\begin{array}{ll}\text { Local wisdom } \\
\text { value }\end{array}$ & Kasiuluran/Kinship & $\begin{array}{l}\text { - Getting along well despite having different } \\
\text { religions } \\
\text { - Communal } \\
\text { - Family comes first }\end{array}$ \\
& & - Religion becomes private \\
& Tengko Situru/ & - Supporting religious activities \\
Togetherness & - Maintaining peace \\
& Karapasan/ & - Feeling shame upon violating customs and \\
Persistence & religions \\
& Obeying religion and customs \\
\hline
\end{tabular}

related to Tongkonan are essential in their spiritual life with their ancestors and their relationship with the nuclear and extended family. Toraja kinship is usually formed in each village consisting of an extended family member. The extended family is then called Tongkonan. Usually, the family has a name used as the village's name (Rima 2019). Many of the old sayings that have become the motto of the Toraja people are related to togetherness. One example of a very popular saying is Misa 'kada dipotuo, Pantan kada dipomate [united we stand, divided we fall] (interview, An, 2020).

Culturally, Torajans firmly adhere to the pepasan to matua [parental message] and internalise their family members. One of the values that teach persistence is karapasan, which in the Toraja language means a persistent effort to keep and maintain harmony and peace even if you have to sacrifice property. The expressions which indicate this concept include unnali melo [buying goodness] or la'biran tallan tu barang apa kela sisarak mira tu rara buku [willing to sacrifice one's property, rather than sacrificing brotherhood] (interview, $\mathrm{Mg}, 2020$ ). This activity is a symbol or place where religious and traditional leaders sit and discuss together to strengthen togetherness and the sense of companionship in the Toraja community (Bachrong \& Ansar 2021). Interaction in the family also contains the value of longko' and siri' - longko' implies tolerance which means to be polite and respectful and not to embarrass people; siri' is inferred as self-respect and shame. Acts done outside of aluk and pemali will lead to sin and siri' that can embarrass not only the individual who commits the sin but also his/her extended family (interview, Mg, 2020).

\section{The roles of religious leaders, institutions, tradition, and family}

In the Indonesian Dictionary (the KBBI dictionary), public figures mean prominent and famous people (Kemdikbud 2020). It means that a character has a significant role in the growth, development, and control of values and norms in a society. They become a reference and model for the people around them in speech, attitude, and behaviour. According to social role theory, a character has an essential role in carrying out his rights and obligations in an organisation. Characters are expected to display the expected behaviour and fulfil social status expectations in a unified system (Muzaki 2010). In this study, the roles of religious leaders, institutions, traditions and family are depicted as ones that can unite the diversity in the community.

In this context, the role is closely related to the status of a figure in carrying out his rights and obligations. The two cannot be separated because they are dependent on one another. According to Ridwan et al. (2019), religious leaders' activities have shifted from being religious leaders to opinion makers. However, this shift has strengthened them as the owner of religious authority (Ridwan et al. 2019). 
From Table 2, it can be deduced that in Tana Toraja, family, religious leaders, indigenous leaders, and community leaders play a huge role in strengthening the quality of tolerance. As religious figures, institutional roles are carried out by; (1) emphasising to community members that religious differences are private and common; (2) respecting differences; and (3) always being present at both traditional and religious events. Meanwhile, the roles of indigenous leaders include the following: (1) encouraging tolerance; (2) protecting all communities of different religions; and (3) teaching and setting an example in fostering peace.

The nuclear families and extended families in Toraja society with ties to Tongkonan respect differences in religion and belief. Even at traditional events, all family members attend and contribute both morally and materially regardless of their religion. Likewise, religious leaders and traditional leaders strongly encourage tolerance, protect all, and teach peace both with religious instruments and customs. With the spirit of karapasan, family members are persistent and steadfast in maintaining unity, and peace in the family, even at the expense of property and material. The expression unnali melo [buying goodness], willing to sacrifice his property rather than abandoning the brotherhood (interview, Mn, 2020). This spirit is still very firmly attached to the Toraja people today and is one of the steadfast pillars of tolerance.

In the Toraja community, traditional leaders known as Parenge, are appointed and elected by the community in a Tongkonan based on lineage, devotion, and mastery of customs to carry out tasks such as resolving conflicts in society (Abdullah, Sultan \& Matande 2018). In this context, clans, religious leaders, and traditional leaders act as institutions that strengthen social cohesion. The existence of equality in meeting needs and interactions creates coalitions. Coalition in any community is integral for improving the quality of life. A well-established interaction will give rise to a balance of power between two or several communities. Social cohesion is not a construction of contemporary discourse. It has long historical roots, starting from theoretical debates about what constitutes a social order in society and why it can be maintained even in times of social change (Agung, Fu'ady \& Surur 2018). Social cohesion is usually seen as a multidimensional construct consisting of phenomena at the micro (e.g. individual attitudes and orientations), meso (community and group features), and macro (social, institutional

\begin{tabular}{|c|c|c|}
\hline Focus & Aspect & Findings \\
\hline \multirow[t]{3}{*}{ Institutional } & Religious figures & $\begin{array}{l}\text { - Religious differences are common } \\
\text { - Respecting the differences } \\
\text { - Coming to the religious/indigenous activities }\end{array}$ \\
\hline & Indigenous figures & $\begin{array}{l}\text { - Supporting tolerance } \\
\text { - Protecting all } \\
\text { - Teaching peace }\end{array}$ \\
\hline & Extended family & $\begin{array}{l}\text { - Teaching tolerance in customs } \\
\text { - Nurturing all religions } \\
\text { - Supporting peace }\end{array}$ \\
\hline
\end{tabular}

features) levels (Schiefer \& Van der Noll 2017). Developing social cohesion also aims to promote cooperation, mutual understanding, and creation of common interests to maintain mutual peace.

\section{Socialisation to strengthen tolerance}

Socialisation is a person's learning process to learn the pattern of life according to values, norms and habits. This definition emphasises the process. It means that socialisation requires a process, which will determine the programme's success in achieving its goals. In the process of socialisation, each individual tries to harmonise their life amid society. Sometimes adjustments must be aligned with the norms and values that apply in their environment, including what can and cannot be done (Narwoko \& Suyanto 2004).

From the results of data analysis, socialisation in strengthening tolerance is carried out in the realm of traditional ceremonies, religion, and social activities (see Table 3).

As seen from Table 3, firstly, the socialisation process is carried out by utilising traditional activities; (1) involve all family members; (2) all family members participate in traditional events even though they are of different religions; (3) provide mutual assistance in the implementation of traditional events. Secondly, socialisation is carried out in the realm of religious activities by the following: (1) visiting each other on religious days such as Eid al-Fitr and Christmas; (2) taking care of each other in the implementation of worship; (3) respecting the religious events of other people. Thirdly, in the social sphere, this is done by; (1) acting together in social activities; (2) providing mutual support in social activities; (3) cleaning the house of worship.

Until now, the Toraja people still maintain the original beliefs of Aluk Todolo, as the beliefs of their ancestors in the form of rituals, customs, and rules. Over time, because of the need for the citizen identification card administration, Aluk Todolo, as the local religion of the Toraja people, was converted to Hinduism (Nazaruddin 1979). Linguistically, Aluk means rules, religion; Todolo means ancestors. So, Aluk Todolo means ancestral religion (Tangdilintin 1974).

Toraja people recognise two main ceremonies involving the life cycle, namely Rambu Tuka (Alluk Rampe Matollo) and Rambu Solo (Alluk Rampe Matampu). The Rambu Tuka ceremony is held to welcome joyful events such as marriage,

TABLE 3: Focus, aspect, and findings on a social level.

\begin{tabular}{lll}
\hline Focus & Aspect & Findings \\
\hline Socialisation & $\begin{array}{l}\text { Indigenous } \\
\text { activities }\end{array}$ & $\begin{array}{l}\text { - All family members present indigenous activities } \\
\text { - Coming to the indigenous activities despite } \\
\text { religious differences }\end{array}$ \\
& $\begin{array}{l}\text { - Helping each other in indigenous activities } \\
\text { Religious } \\
\text { activities }\end{array}$ & $\begin{array}{l}\text { - Visiting each other on Christmas/Eid } \\
\text { - Protecting each other in praying }\end{array}$ \\
& $\begin{array}{l}\text { Community } \\
\text { activities }\end{array}$ & - Participating in any activities in their \\
& - Peighbourhood \\
& - Working together in cleaning religious places
\end{tabular}


harvesting (Alluk Pare), or entering a new house (Mangrara Banua). While Rambu Solo 'is a reversal ceremony of the soul that died before being buried. Carrying out the Rambu Solo ceremony for parents' bodies is the primary obligation of every child in the life of the Toraja tribe (interview, Mn, 2020).

This togetherness is not only seen in traditional ceremonies, but also in social and religious events. In every religious celebration, such as Christmas and New Year, Muslims are invited to attend the event. Sometimes they bring their own food, or it is cooked with special equipment (interview, Mn, 2020). There is no disrespect towards one another because it has become an unwritten agreement between the family and the Toraja community in general to respect all religions and all people. If there is construction or rehabilitation of a church, Muslims help with labour, such as levelling the yard or carrying bricks. On the other hand, if there is construction or renovation of a mosque, Christians will also help with the energy. Religious, customary, and community leaders without exception encourage inter-religious harmony through the culturalisation of Tongkonan values in the family.

Families use religious celebrations to build coexistence. Within the big multi-cultural families, Christmas, New Year, Eid al-Fitr and Eid al-Adha celebrations offer precious moments to implement the principle of togetherness with their extended family of different religions. When Christmas arrives, Muslim families invite other family members to provide moral and material assistance but do not participate in the Christmas sacrament because it is believed to be against the Islamic creed (interview, Mn, 2020). The family that consisted of many different religions was built on the awareness that religion and belief are impossible to unite in the theological area. Still, sociologically they could unite and provide support to one another. Inter-religious harmony in Indonesia has survived because of the empathy nurtured since childhood, encouraging interaction and communication among the community without caring about religious differences. When Islam and Christianity entered the village, this tradition was adapted to maintain the community's unity, harmony, and civility, so that inter-religious harmony creates a sense of nationality (Sinaga, Tanjung \& Nasution 2019).

Pdt. Hendrik Lewy Payung from the Pentecostal Church in Indonesia (GPdI) in Tana Toraja stated that Toraja people place brotherhood based on blood ties as sacred as a brotherhood in religion. Commitment to culture and the religion adopted to strengthen a collaborative culture brings together the noble values of culture and religion in harmony (interviews: HLP, FL, MJ, 2020). In traditional societies, traditional parties can be the primary momentum to mobilise workers, increase socio-political power, and build and consolidate the meaning of relationships (Adams 2004). One theory that can be used to support socialisation and interaction in society is the theory of symbolic interaction. The theory of symbolic interaction is influenced by social structures that shape or cause certain behaviours, forming symbols in people's social interactions. Symbolic interaction sees social reality created by humans who can interact symbolically, have the essence of culture, interact with each other, and socialise.

From the analysis above, the critical role that the local culture, traditional leaders, and religious leaders play in the religious moderation, social integration and the practice of tolerance in Indonesia can be inferred clearly. These three instruments are often marginalised or only get a place during electoral political activities such as General Elections and Pilkada to gain support. As a matter of fact, local wisdom characterises the ability to defend certain cultures against outside influences, accommodate elements from other cultures, and then integrate them into their lives (Pesurnay 2018), which is strengthened by traditional and religious leaders role in disseminating these values. Thus, the strategy in strengthening tolerance in a multi-ethnic and religious area such as Indonesia must integrate the involvement of traditional leaders, religious leaders, and local cultural values to realise social integration.

\section{Conclusion}

This study concludes that moderate religious practice is internalised in families with local wisdom values, namely kasiuluran [kinship], tengko situru' [togetherness], and karapasan [tenacity]. In the institutional aspect, religious leaders, both Muslim and non-Muslim, actively campaign for tolerance between religious communities, protecting all religions, and teaching peace. Likewise, traditional leaders and families emphasise tolerance in Tongkonan ties. Religious leaders, customs, and Tongkonan clans are social capital for the Toraja people to culturalise the value of tolerance in the nuclear family as well as the extended family. In socialisation, the Toraja people utilise traditional activities, religious activities, and social activities to build positive and dynamic interactions. They (Muslims and non-Muslims) visit each other during religious and customary celebrations.

Theoretically, the research contributes to building a very empirical relationship between local wisdom and absolute religion. The discourse of religious moderation by relying on national commitment, tolerance, anti-violence, and being accommodative to local culture will be strengthened by the results of this research. Meanwhile, practically, this research becomes a model for regions with similar characteristics to their locus to take advantage of the value of local wisdom and moderate religious understanding to build strong tolerance among religious adherents.

There are some limitations for this research. Firstly, this research was conducted in an area with unique characteristics and is ethnically homogeneous, so it requires expansion to be applied to other areas. Secondly, the subjectivity of informants may occur during the interview process. The researchers recommend that further researchers pay attention to more heterogeneous areas with the purpose that tolerance between religious communities can be depicted. 


\section{Acknowledgements}

The authors would like to thank the Chancellor of the Muhammadiyah Palopo University and the Head of the Institute for Research and Community Service for supporting the implementation of this research. The results of this study are entirely the responsibility of the authors.

\section{Competing interests}

The authors declare that they have no financial or personal relationships that may have inappropriately influenced them in writing this article.

\section{Authors' contributions}

H.P., I.P., and P.S. contributed to the design and implementation of the research, to the analysis of the results and to the writing of the manuscript.

\section{Ethical considerations}

This article followed all ethical standards for research.

\section{Funding information}

This research received no specific grant from any funding agency in the public, commercial or not-for-profit sectors.

\section{Data availability}

Data sharing is not applicable to this article as no new data were created or analysed in this study.

\section{Disclaimer}

The views and opinions expressed in this article are those of the authors and do not necessarily reflect the official policy or position of any affiliated agency of the authors.

\section{References}

Abdullah, S., Sultan \& Matande, R.S., 2018, 'The meaning of local to Parenge's authority in the resolution of land conflict in Tana Toraja', Dialetika 13(1), 122131. https://doi.org/10.20473/jsd.v13i2.2018.122-131

Adams, R.L., 2004, 'An ethnoarchaeological study of feasting in Sulawesi, Indonesia', Journal of Anthropological Archaeology 23(1), 56-78. https://doi.org/10.1016/j. jaa.2003.10.001

Agung, Y.R., Fu'ady, M.A. \& Surur, M., 2018, 'Kohesi sosial dalam membentuk harmon kehidupan komunitas', Jurnal Psikologi Perseptual 3(1), 37-43. https://doi. org/10.24176/perseptual.v3i1.3679

Arifinsyah, A., Andy, S. \& Damanik, A., 2020, 'The urgency of religious moderation in preventing radicalism in Indonesia', ESENSIA: Jurnal IImu-IImu Ushuluddin 21(1), 91-108. https://doi.org/10.14421/esensia.v21i1.2199

Astuti, T.M.P., Kurniawan, E., Setyowati, D.L., Syifauddin, M. \& Machmud, A., 2019 'Living tourism and tolerance tourism of a multicultural society in lasem, rembang, central Java', International Journal of Innovation, Creativity and Change 8(6), 319-331.

Bachrong, F. \& Ansar, F.A., 2021, 'Religious moderation in Karapasan the local culture of Tana Toraja community in South Sulawesi', Al-Qalam 27(1), 63. https://doi. org/10.31969/alq.v27i1.973

Bigalke, T.W., 2005, Tana Toraja: A social history of an Indonesian people, NUS Press, Singapore.

Bungin, B., 2009, Analisis Penelitian Data Kualitatif, Raja Grafindo, Jakarta.

Departemen Agama, R.I., 2005, Alquran dan terjemah, Al Jumanatul â€ Ali, Bandung.
Dodego, S.H.A. \& Witro, D., 2020, 'The Islamic moderation and the prevention of radicalism and religious extremism in Indonesia', Dialog 43(2), 199-208. https:// doi.org/10.47655/dialog.v43i2.375

Effendi, T.D., 2019, 'Local wisdom in tolerance building between ethnic Chinese and other ethnics in Indonesia', Advances in Social Science, Education and Humanities Research 276, 203-206. https://doi.org/10.2991/iconarc-18.2019.104

Frydenlund, I., 2015, The rise of Buddhist-Muslim conflict in Asia and possibilities for transformation, Norwegian Peacebuilding Research Centre (NOREF), Norway.

Glazier, R.A., 2018, 'How religion influences peacemaking', Peace and Conflict Studies 25(2), 3. https://doi.org/10.46743/1082-7307/2018.1452

Hammarberg, K., Kirkman, M. \& De Lacey, S., 2016, 'Qualitative research methods: When to use them and how to judge them', Human Reproduction 31(3), 498-501. https://doi.org/10.1093/humrep/dev334

Handayani, R., Ahimsa-Putra, H.S. \& Budiman, C., 2020, 'Out of crisis: Maintaining hegemony through Rambu Solo Ritual in Toraja', KOMUNITAS: International Journal of Indonesian Society and Culture 12(2), 246-258.

Haryanto, J.T., 2015, 'Relasi Agama dan Budaya dalam Hubungan Intern Umat Islam', Jurnal SMART (Studi Masyarakat, Religi, Dan Tradisi) 1(1), 41-54. https://doi. org/10.18784/smart.v1i1.228

Hasan, M., 2018, 'Wasatiyyah Islam in the framework Pesantren education tradition', KARSA: Journal of Social and Islamic Culture 26(2), 177-194. https://doi. org/10.19105/karsa.v26i2.2047

Hernawan, W., Riyani, I., Busro, B., State, I. \& Bandung, D., 2021, 'Religious moderation in Naskah Wawacan Babad Walangsungsang: A Sundanese religious diversity wisdom', HTS Teologiese Studies/Theological Studies 77(4), 1-13. https://doi. wisdom', HTS Teologiese Stud
org/10.4102/hts.v77i4.6773

Hidayat, S., 2015, 'Urgensi cultural approach Sebagai Metodologi Keilmuan dalam Pendidikan Islam Kontemporer', Al-Hikmah 7(1), 51-65. https://doi.org/10.24260/ al-hikmah.v7i1.53

Husna, U. \& Thohir, M., 2020, 'Religious moderation as a new approach to learning Islamic religious education in schools', Nadwa: Jurnal Pendidikan Islam 14(1), 199-222. https://doi.org/10.21580/nw.2020.14.1.5766

Ibrahim, I., Prasojo, Z.H. \& Sulaiman, S., 2019, 'Preventing radicalism: Islamic moderation and revitalization in the border', Wawasan: Jurnal IImiah Agama Dan Sosial Budaya 4(1), 1-15. https://doi.org/10.15575/jw.v4i1.4400

Idaman, I., 2012, 'Religious ritual as a contestation arena: The experiences of Aluk Todolo community in Tana Toraja of South Sulawesi', JICSA (Journal of Islamic Civilization in Southeast Asia) 1(1), 141-173.

Junaedi, E., 2019, 'Inilah Moderasi Beragama Perspektif Kementerian Agama', Jurna Multikultural \& Multireligius 18(2), 182-186. https://doi.org/10.32488/harmoni. v18i2.414

Kemdikbud, P.B., 2020, 'Kamus Besar Bahasa Indonesia Edisi Kelima (KBBI V)', Diakses Pada 19.

Kementrian Agama RI, 2019, Moderasi Beragama, Badan Litbang dan Diklat Kementerian Agama RI, Jakarta.

Latif, Y., 2011, Negara Paripurna: Historisitas, Rasionalitas, dan Aktualitas Pancasila PT, Gramedia Pustaka Utama, Jakarta.

Markus, A., 2017, Multiculturalism discussion paper young adults and cultura diversity: Experiences and challenges discussion paper, Scanlon Foundation, Monash University, Australia, September.

Mattulada, H.A., 1982, 'South Sulawesi, its ethnicity and way of life', Southeast Asian Studies 20(1), 4-22.

Mattulada, H.A., 2015, Latoa: Antropologi Politik Orang Bugis, Penerbit Ombak, Jogjakarta.

Miftah, M., 2016, 'Multicultural education in the diversity of national cultures', QIJIS (Qudus International Journal of Islamic Studies) 4(2), 167-185. https://doi. org/10.21043/qijis.v4i2.1766

Muhajir, A., 2018, Membangun Nalar Islam Moderat Kajian Metodologis, Tanwirul Afkar, Situbondo.

Muhiddin, S., Zuharyadi S.A., Achmadan, F. \& Awaluddin, I., 2020, 'Studi Tentang Konsep Diri Orang Toraja, Perspektif Psikologi Kebudayaan', Jurnal Psikologi 9(2), 1-18. https://doi.org/10.13140/RG.2.2.13962.82889

Mu'ti, A. \& Islam, I., 2009, Inkulturasi Islam: Menyemai Persaudaraan, Keadilan, dan Emansipasi Kemanusiaan, Keadilan, Dan Emansipasi Kemanusiaan, Al-Washat Publishing House, Jakarta.

Muzaki, M., 2010, 'Partisipasi Tokoh Masyarakat Dalam Toleransi Umat Beragama', KOMUNIKA: Jurnal Dakwah Dan Komunikasi 4(1), 160-177. https://doi. org/10.24090/komunika.v4i1.145

Nakaya, A., 2018, 'Overcoming ethnic conflict through multicultural education: The case of West Kalimantan, Indonesia', International Journal of Multicultural Education 20(1), 118-137. https://doi.org/10.18251/ijme.v20i1.1549

Narwoko, J.D. \& Suyanto, B., 2004, Sosiologi teks pengantar dan terapan, Prenada Media, Jakarta.

Nazaruddin, N., 1979, Kelahiran dan pengasuhan anak di Desa Banga, Kecamatan Saluputti, Kabupaten Tana Teraja, Diterbitkan oleh Hasanuddin University Press untuk Pusat Latihan Penelitia, Makassar.

Pajarianto, H. \& Mahmud, N., 2019, 'Model Pendidikan dalam Keluarga Berbasis Multireligius', Lentera Pendidikan: Jurnal Ilmu Tarbiyah Dan Keguruan 22(2), 254266. https://doi.org/10.24252/Ip.2019v22n2i7

Pesurnay, A.J., 2018, 'Local wisdom in a new paradigm: Applying system theory to the study of local culture in Indonesia', IOP Conference Series: Earth and 
Environmental Science 175(1), 12037. https://doi.org/10.1088/17551315/175/1/012037

Prasojo, Z.H., Elmansyah, E. \& Haji Masri, M.S., 2019, 'Moderate Islam and the social construction of multi-ethnic communities', Indonesian Journal of Islam and Muslim Societies 9(2), 217-239. https://doi.org/10.18326/ijims.v9i2.217-239

Pulubuhu, D.A.T., Radjab, M., Ab Rahman, A.H. \& Haris, A., 2019, 'The social meaning of Rambu Solo ceremony in Toraja (the perspective of symbolic interactionism theory)', The Journal of Social Sciences Research 5(3), 778-781. https://doi. org/10.32861/jssr.53.778.781

Rahardjo, S., 2002, Peradaban Jawa: dinamika pranata politik, agama, dan ekonomi Jawa kuno, Komunitas Bambu, Jakarta.

Ridwan, B., Syahputra, I., Tarigan, A.A., Siregar, F.A., 2019, 'Islam Nusantara, ulemas, and social media: Understanding the pros and cons of Islam Nusantara among ulemas of West Sumatera', Indonesian Journal of Islam and Muslim Societies 9(2), 163-188. https://doi.org/10.18326/IJIMS.V9I2.163-188

Rima, G., 2019, 'Persepsi mayarakat Toraja pada upacara adat Rambu Solo'dan implikasinya terhadap kekerabatan masyarakat di Kecamatan Makale Kabupaten Tana Toraja', Phinisi Integration Review 2(2), 227-237. https://doi.org/10.26858/ pir.v2i2.10000

Rogers, B., 2018, 'Rejecting religious intolerance in South-East Asia', JSEAHR 2, 208 https://doi.org/10.19184/jseahr.v2i1.7587

Schiefer, D. \& Van der Noll, J., 2017, 'The essentials of social cohesion: A literature review', Social Indicators Research 132(2), 579-603. https://doi.org/10.1007/ s11205-016-1314-5

Shihab, M.Q., 2019, Wasathiyyah Wawasan Islam tentang Moderasi Beragama, Lentera Hati, Tangerang.

Sinaga, R., Tanjung, F. \& Nasution, Y., 2019, 'Local wisdom and national integration in Indonesia: A case study of inter-religious harmony amid social and political upheaval in Bunga Bondar, South Tapanuli', Journal of Maritime Studies and National Integration 3(1), 30. https://doi.org/10.14710/jmsni.v3i1.4482
Singh, A., 2018, 'Conflict between freedom of expression and religion in India - A case study', Social Sciences 7(7), 108. https://doi.org/10.3390/socsci7070108

Sugiyono, S., 2017, 'Combination research methods (mixed methods)', Alfabeta, Bandung.

Sumadi, T., Yetti, E., Yufiarti, Y. \& Wuryani, W., 2019, 'Transformation of tolerance values (in religion) in early childhood education', JPUD-Jurnal Pendidikan Usia Dini 13(2), 386-400. https://doi.org/10.21009/jpud.132.13

Suparto, S., 2009, 'Dakwah Kultural Muhammadiyah antara Pembaruan dan Pembauran', El Harakah 11(2), 155. https://doi.org/10.18860/el.v0i0.430

Syarif, F., 2019, 'Religion in the conflict flows', ADDIN 13(2), 337-368. https://doi. org/10.21043/addin.v13i2.6452

Tambunan, S.F., 2018, 'Adat and religious tolerance: Ethnophilosophy perspective', Journal of Indonesian Social Sciences and Humanities 8(2), 89-100. https://doi. org/10.14203/jissh.v8i2.135

Tangdilintin, L.T., 1974, Toraja dan kebudayaannya, Kantor Cabang II, Lembaga Sejarah \& Antropologi.

Umar, P., 2019, 'Torayaan Mencipta Harmoni Merayakan Kerukunan (Praktik Kerukunan Umat Beragama di Tondok Lepongan Bulan Tana Toraja)', Al-Qalam 25(2), 321-340. https://doi.org/10.31969/alq.v25i2.744

Verkuyten, M., Yogeeswaran, K. \& Adelman, L., 2019, 'Intergroup toleration and its implications for culturally diverse societies', Social Issues and Policy Review 13(1), 5-35. https://doi.org/10.1111/sipr.12051

Wani, H., Abdullah, R. \& Chang, L.W., 2015, 'An Islamic perspective in managing religious diversity', Religions 6(2), 642-656. https://doi.org/10.3390/rel6020642

Waterson, R., 2009, Paths and rivers: Sa'dan Toraja society in transformation, Vol. 253, NUS Press, Singapore.

Yazdani, A., 2020, 'The culture of peace and religious tolerance from an Islamic perspective', Veritas 47, 151-168. https://doi.org/10.4067/S0718P273202000300151 